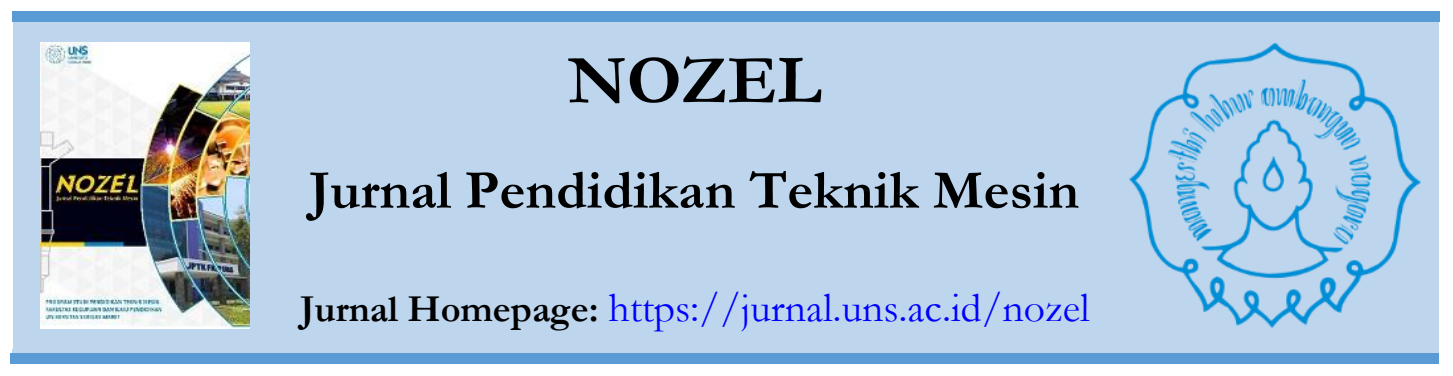

\title{
PENGARUH PENGGUNAAN TIPE ELEKTROLISER DAN JENIS LARUTAN PADA HYDROGEN ECO BOOSTER TERHADAP EMISI GAS BUANG SEPEDA MOTOR 4 TAK
}

\author{
Abdul 'Aziz Manggala Saputra ${ }^{1}$, Ranto $^{1}$, Basori ${ }^{1}$ \\ ${ }^{1}$ Program Studi Pendidikan Teknik Mesin, FKIP, Universitas Sebelas Maret Surakarta \\ e-mail: abizmantra@gmail.com
}

\begin{abstract}
The purpose of this research are: (1) Investigate the influence of the type of electrolyzer on Hydrogen Eco Booster towards the level of exhaust emissions (CO and HC) 4 stroke motorcycle. (2) Investigate the influence of the kind of solvent on Hydrogen Eco Booster towards the level of exhaust emissions (CO and $\mathrm{HC}$ ) 4 stroke motorcycle. (3) Investigate the influence of the type of electrolyzer and the kind of solvent on Hydrogen Eco Booster towards the level of exhaust emissions (CO and HC) 4 stroke motorcycle. This research was conducted at the Automotive Laboratory of Mechanical Engineering Education, Teacher Training and Education Faculty Sebelas Maret University of Surakarta used a Honda Supra X 125 motorcycle, year of manufacture 2013. This study is an experimental research. The method of collecting data used in the research is measurement method. The data obtained from the test results were analyzed using Two-Way Anova Test and followed by One-Sample T Test and Scheffe Test. The results of this research are: (1) There is a significance effect on the type of electrolyzer on Hydrogen Eco Booster towards to decrease the level of exhaust emissions (CO and HC) 4 stroke motorcycle, (Sig-value of $\mathrm{CO}$ gas $=0.001<$ $\alpha=0.05$ ) and (Sig-value of HC gas $=0.000<\alpha=0.05$ ). (2) There is a significance effect on the kind of solvent on the Hydrogen Eco Booster towards to decrease the level of exhaust emissions (CO and HC) 4 stroke motorcycle, (Sig-value of CO gas $=0.000<$ $\alpha=0.05$ ) and (Sig-value of HC gas $=0.000<\alpha=0.05$ ). (3) There is a significance effect interaction between the type of electrolyzer and the kind of solvent on the Hydrogen Eco Booster towards to decrease the level of exhaust emissions (CO and HC) 4 stroke motorcycle, (Sig-value of CO gas $=0.000<\alpha=0.05$ ) and (Sig-value of HC gas=0.000 $<\alpha=0.05)$. The lowest $C O$ gas obtained on the Wet Cell type using the kind of solvent $\mathrm{KOH}$ with a decrease of $84.41 \%$. The lowest HC gas obtained on the Dry Cell type using the kind of solvent $\mathrm{NaOH}$ with a decrease of $69.62 \%$.
\end{abstract}

Keywords: Hydrogen eco booster, type of electrolyzer, the kind of electrolyte solvent, exhaust emission 


\section{A. PENDAHULUAN}

Jumlah alat transportasi khususnya sepeda motor bertambah banyak seiring kebutuhan manusia yang meningkat. Peningkatan jumlah sepeda motor tersebut memicu terjadinya kemacetan dan bertambahnya polusi udara yang disebabkan oleh emisi gas buang kendaraan. Emisi gas buang dapat mencemari lingkungan karena mengandung gas $\mathrm{HC}$ dan gas $\mathrm{CO}$. Gas $\mathrm{HC}$ dapat menyebabkan gangguan saluran pernafasan sedangkan Gas CO juga sangat berbahaya, karena dapat menghambat pasokan oksigen jika masuk ke dalam tubuh manusia.

Pemerintah melalui Peraturan Menteri Lingkungan Hidup Nomor 23 Tahun 2012 mengatur pihak produsen maupun konsumen wajib melakukan uji emisi gas buang kendaraan. Emisi gas buang dapat diuji dengan teknologi yang dapat diterapkan untuk membatasi emisi gas buang diantaranya Catalytic Converter, Air Injection, dan rekayasa penggunaan bahan bakar.

Permintaan bahan bakar minyak meningkat seiring dengan bertambahnya jumlah sepeda motor. Hal itu mengakibatkan, ketersedian BBM semakin lama semakin menipis. BBM termasuk bahan bakar fosil. Ketersediaan bahan bakar fosil ini semakin berkurang. Padahal, Indonesia kaya akan keragaman sumber daya alam mulai dari tanah, air, angin, panas bumi hingga panas matahari yang berpotensi menjadi sumber energi baru yang terbarukan (EBT) dan dapat menggantikan bahan bakar fosil. Namun potensi EBT saat ini belum dimanfaatkan secara optimal.

Air merupakan salah satu sumber EBT yang tersedia melimpah di muka bumi termasuk di Indonesia. Elektrolisis air menghasilkan gas hidrogen dan oksigen atau gas hidrogen hidrogen oksida (HHO) atau sering dikenal sebagai Brown gas yang diambil dari nama penemunya yaitu Yull Brown. Sudirman (2009: 8) mengatakan bahwa Brown gas merupakan bahan bakar yang kuat (powerfull), bersih, mampu meningkatkan jarak tempuh, dan mengurangi secara signifikan emisi gas buang. Gas hidrogen dapat membantu pembakaran rantai hidrokarbon dari BBM dan gas oksigen dapat mengurangi emisi gas $\mathrm{CO}$ dengan membantunya membentuk gas $\mathrm{CO}_{2}$.

\section{Emisi Gas Buang}

Gas buang merupakan sisa pembakaran dari kendaraan bermotor. Tinggi rendahnya emisi gas buang tersebut dipengaruhi oleh nilai Lambda. Nilai Lambda dirumuskan sebagai berikut: 


$$
\lambda=\frac{\text { jumlah pasokan udara }}{14,7}
$$

Nilai lambda merupakan perbandingan antara jumlah pasokan udara dengan jumlah udara ideal dalam pembakaran sempurna. Pada pembakaran yang ideal, rasio antara udara dan bahan bakar (air fuel ratio) adalah 14,7:1.

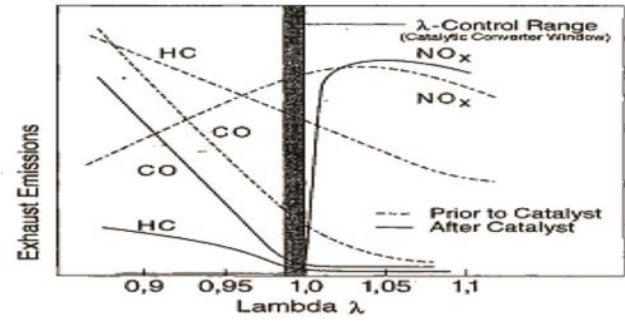

Gambar 1. Pengaruh Lambda terhadap Gas Buang

Apabila nilai $\lambda=1$ maka pembakaran dinyatakan sempurna, karena emisi gas buang kendaraan dapat ditekan seminimal mungkin. Jika nilai $\lambda<1$ maka pembakaran berlangsung pada campuran kaya yang menyebabkan emisi gas $\mathrm{CO}$ dan $\mathrm{HC}$ meningkat drastis disebabkan bahan bakar tidak terbakar seluruhnya. Jika nilai $\lambda>1$ maka pembakaran berlangsung pada campuran miskin yang menyebabkan emisi gas $\mathrm{NO}_{\mathrm{x}}$ meningkat drastis karena suhu ruang bakar menjadi tinggi dan jumlah gas oksigen meningkat menyebabkan gas nitrogen akan terpecah sehingga membentuk gas $\mathrm{NO}_{\mathrm{x}}$.

\section{Gas HHO}

Gas HHO diperoleh dari proses elektrolisis air. Elektrolisis adalah pemisahan air menjadi unsur-unsur penyusunnya dengan mengalirkan arus listrik searah kedalam air melalui elektroda. Dua molekul air bereaksi menangkap dua elektron pada katoda yang tereduksi menjadi gas $\mathrm{H}_{2}$ dan ion hidroksida $\left(\mathrm{OH}^{-}\right)$. Pada kutup anoda dua molekul air lainnya akan terurai menjadi gas oksigen $\left(\mathrm{O}_{2}\right)$ dengan melepas 4 ion $\mathrm{H}^{+}$ serta mengalirkan elektron ke katoda. Akibat reaksi tersebut gas hidrogen akan terkumpul di katoda dan gas oksigen akan terkumpul di anoda, dan ion $\mathrm{H}^{+}$dan $\mathrm{OH}^{-}$ akan mengalami netralisasi dan membentuk molekul air kembali.

Reaksi kimia saat gas brown bercampur dengan bahan bakar dan udara dapat dituliskan sebagai berikut:

$\mathrm{HHO}_{(\mathrm{g})}+\mathrm{C}_{8} \mathrm{H}_{18}+9 \mathrm{O}_{2} \rightarrow 9 \mathrm{H}_{2} \mathrm{O}_{(\mathrm{g})}+4 \mathrm{CO}_{8}+2 \mathrm{CO}+2 \mathrm{HC}$

\section{Hydrogen Eco Booster}

Istilah dari Hydrogen Eco Booster sebenarnya sama dengan istilah elektroliser. Hydrogen Eco Booster terdiri dari kata Hydrogen, Eco, dan Booster. Hydrogen yang berarti gas hidrogen, Eco dapat berarti hemat atau ekonomis, dan Booster yang berarti penambah. Hydrogen Eco Booster adalah alat (generator) yang menambah produksi gas hidrogen (dan 
oksigen) sehingga dapat menghemat bahan bakar.

Dalam penelitian ini, emisi gas buang sepeda motor diukur dengan penambahan gas HHO yang dihasilkan dari Hydrogen Eco Booster tipe elektroliser yang digunakan ada dua macam yaitu elektroliser tipe basah (Wet Cell) dan elektroliser tipe kering (Dry Cell), sedangkan jenis larutan yang digunakan adalah air murni, air murni dengan tambahan katalis $(\mathrm{KOH}, \mathrm{NaOH}$, dan $\mathrm{NaHCO}_{3}$ ) masing-masing sebanyak 12 gram tiap 1 liter air.

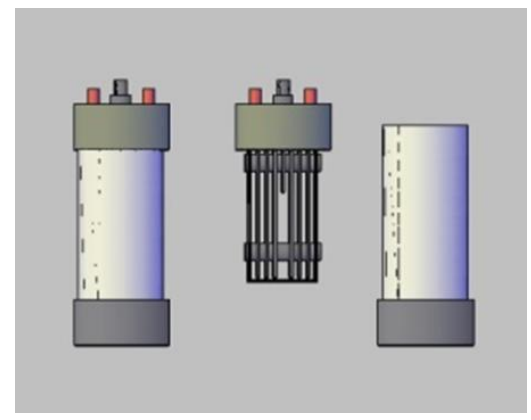

Gambar 2. Hydrogen Eco Booster tipe Wet Cell

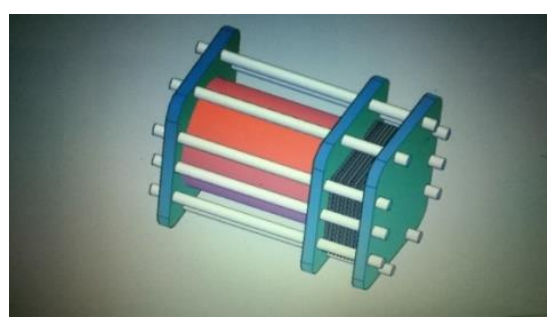

Gambar 3. Hydrogen Eco Booster tipe Dry Cell

\section{B. METODE PENELITIAN}

Penelitian ini merupakan jenis penelitian kuantitatif eksperimen. Pengujian emisi gas buang mengacu pada SNI 09-7118.3-2005 dari Badan Standardisasi Nasional (BSN) tentang cara uji kendaraan bermotor kategori L pada kondisi Idle. Penelitian ini dilaksanakan di Laboratorium Otomotif Program Studi Pendidikan Teknik Mesin FKIP UNS Surakarta dengan menggunakan alat Gas Analyzer Technotest tipe STARGAS 898.

Populasi dalam penelitian ini adalah sepeda motor 4 tak dengan sampel adalah sepeda motor Honda Supra X 125 tahun 2013. Teknik pengambilan sampel yang digunakan adalah teknik sampel bertujuan (purposive sampling). Metode pengumpulan data yang digunakan adalah metode pengukuran.

Hasil pengukuran uji emisi dianalisis menggunakan Analisis Variansi (ANAVA) dua jalan dan dilanjutkan dengan uji lanjut pasca Anava Dua Jalan dengan menggunakan Uji T satu sampel dan Uji Scheffe menggunakan bantuan software SPSS versi 23. 


\section{HASIL DAN PEMBAHASAN}

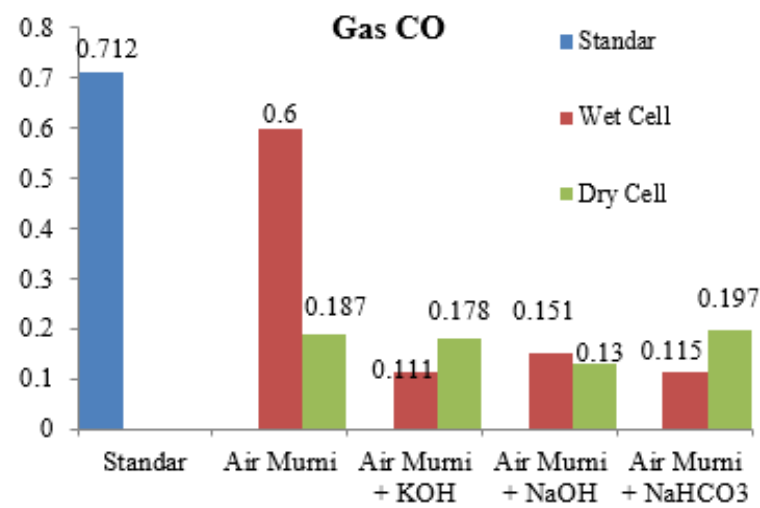

Gambar 5. Perbandingan Emisi Gas Buang CO Sepeda Motor Standar dan dengan Menggunakan $H E B$

Berdasarkan grafik pengujian emisi gas buang tersebut dapat diketahui bahwa rata-rata emisi gas $\mathrm{CO}$ pada kondisi standar atau tanpa menggunakan HEB sebesar 0,712\% dan gas HC sebesar 1.726 ppm lebih tinggi bila dibandingkan dengan menggunakan Hydrogen Eco Booster.

\section{Gas HC}

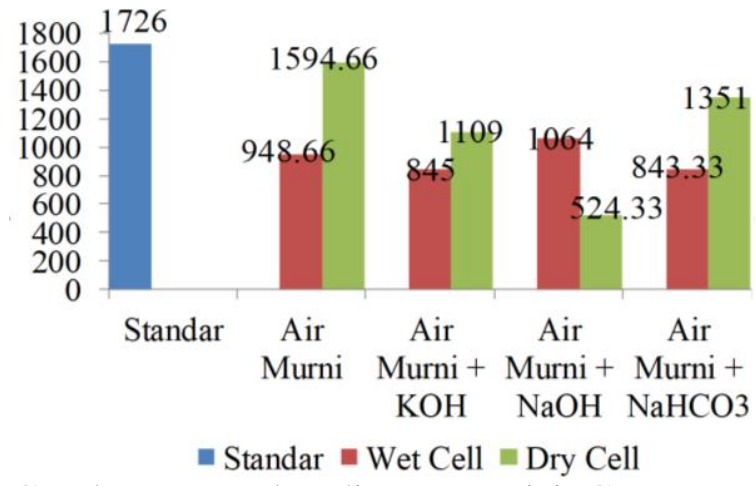

Gambar 7. Perbandingan Emisi Gas Buang HC Sepeda Motor Standar dan dengan Menggunakan $H E B$

Penurunan gas buang tersebut bervariasi sesuai dengan variasi tipe elektroliser dan jenis larutan yang digunakan. Dengan kata lain penggunaan Hydrogen Eco Booster menyebabkan terjadinya penurunan emisi gas buang $\mathrm{CO}$ dan HC.

\section{Hasil Uji Persyaratan Analisis}

Sebelum melaksanakan pengujian hipotesis penelitian, terlebih dahulu dilakukan uji persyaratan analisis yang meliputi uji normalitas dan uji homogenitas.

\section{Uji Normalitas Data}

Pengujian normalitas data ini menggunakan program SPSS versi 23 dengan metode Shapiro-Wilk, dengan taraf kepercayaan $\alpha=5 \%$. Berdasarkan hasil analisis diperoleh nilai signifikansi untuk masing-masing varian lebih besar dari 0,05 maka dapat disimpulkan data hasil uji emisi gas buang $\mathrm{CO}$ dan $\mathrm{HC}$ berdistribusi normal.

\section{Uji Homogenitas Data}

Pengujian homogenitas data ini menggunakan program SPSS versi 23 dengan Levene-Statistic, dengan taraf kepercayaan $\alpha=5 \%$. Berdasarkan hasil analisis diperoleh nilai signifikansi gas $\mathrm{CO}$ yaitu 0,152 dan nilai signifikansi gas $\mathrm{HC}$ yaitu 0,169 masing-masing lebih besar dari 0,05 maka dapat disimpulkan data hasil uji emisi gas buang $\mathrm{CO}$ dan $\mathrm{HC}$ bersifat homogen. 


\section{Uji ANAVA Dua Jalan}

Uji Anava Dua Jalan menggunakan program SPSS versi 23, dengan taraf signifikansi $\alpha=5 \%$.

Tabel 1. Ringkasan Hasil Uji Anava Dua Jalan Emisi Gas Buang CO

\begin{tabular}{|c|c|c|c|}
\hline Varian & Kriteria & Sig. & $\begin{array}{c}\text { Kesimpula } \\
\mathbf{n}\end{array}$ \\
\hline Variasi & Sig. < & 0,00 & Ada \\
\hline Tipe & 0,05 & 1 & $\begin{array}{l}\text { pengaruh } \\
\text { signifikan }\end{array}$ \\
\hline Variasi & Sig. $<$ & 0,00 & Ada \\
\hline Larutan & 0,05 & 0 & $\begin{array}{l}\text { pengaruh } \\
\text { signifikan }\end{array}$ \\
\hline $\begin{array}{c}\text { Variasi } \\
\text { Tipe } \\
\text { dan } \\
\text { Larutan }\end{array}$ & $\begin{array}{c}\text { Sig. }< \\
0,05\end{array}$ & $\begin{array}{c}0,00 \\
0\end{array}$ & $\begin{array}{c}\text { Ada } \\
\text { pengaruh } \\
\text { signifikan }\end{array}$ \\
\hline
\end{tabular}

Tabel 2. Ringkasan Hasil Uji Anava Dua Jalan Emisi Gas Buang HC

\begin{tabular}{|c|c|c|c|}
\hline Varian & Kriteria & Sig. & $\underset{n}{\text { Kesimpula }}$ \\
\hline Variasi & Sig. < & 0,00 & Ada \\
\hline Tipe & 0,05 & 0 & $\begin{array}{l}\text { pengaruh } \\
\text { signifikan }\end{array}$ \\
\hline Variasi & Sig. < & 0,00 & Ada \\
\hline Larutan & 0,05 & 0 & $\begin{array}{l}\text { pengaruh } \\
\text { signifikan }\end{array}$ \\
\hline $\begin{array}{l}\text { Variasi } \\
\text { Tipe } \\
\text { dan } \\
\text { Larutan }\end{array}$ & $\begin{array}{c}\text { Sig. }< \\
0,05\end{array}$ & $\begin{array}{c}0,00 \\
0\end{array}$ & $\begin{array}{c}\text { Ada } \\
\text { pengaruh } \\
\text { signifikan }\end{array}$ \\
\hline
\end{tabular}

Berdasarkan ringkasan hasil uji Anava

Dua Jalan pada Tabel di atas dapat diambil keputusan uji yaitu: (1) Ada pengaruh yang signifikan tipe elektroliser pada Hydrogen Eco Booster terhadap penurunan tingkat emisi gas buang (CO dan HC) sepeda motor 4 tak, (2) Ada pengaruh yang signifikan jenis larutan pada Hydrogen Eco Booster terhadap penurunan tingkat emisi gas buang ( $\mathrm{CO}$ dan HC) sepeda motor 4 tak, (3) Ada interaksi pengaruh yang signifikan antara tipe elektroliser dan jenis larutan pada Hydrogen Eco Booster terhadap penurunan tingkat emisi gas buang $(\mathrm{CO}$ dan HC) sepeda motor 4 tak.

\section{Uji Lanjut Pasca ANAVA Dua Jalan}

Uji lanjut untuk membandingkan masing-masing rerata dengan kondisi standar secara lebih jelas. Uji lanjut pasca anava dua jalan menggunakan program SPSS versi 23 dengan uji $\mathrm{T}$ satu sampel dan uji Scheffe dengan taraf signifikansi $\alpha$ $=5 \%$.

\section{Uji T Satu Sampel}

Tabel 3. Ringkasan Hasil Uji $\mathrm{T}$ Satu Sampel Emisi Gas Buang CO Variasi Tipe Elektroliser dengan Kondisi Standar

\begin{tabular}{lccc}
$\begin{array}{c}\text { Sumber } \\
\text { Perbedaan }\end{array}$ & $\begin{array}{c}\text { Krite- } \\
\text { ria }\end{array}$ & Sig. & $\begin{array}{c}\text { Kesimpu- } \\
\text { lan }\end{array}$ \\
\hline Wet Cell & Sig. $<$ & 0,000 & Berbeda \\
$><$ Standar & 0,05 & & $\begin{array}{c}\text { Signifikan } \\
\text { Berbeda }\end{array}$ \\
Dry Cell & Sig. $<$ & 0,000 & $\begin{array}{c}\text { Signifikan } \\
><\text { Standar }\end{array}$ \\
0,05 & & Signa \\
\hline
\end{tabular}

Tabel 4. Ringkasan Hasil Uji T Satu Sampel Emisi Gas Buang HC Variasi Tipe Elektroliser dengan Kondisi Standar

\begin{tabular}{lccc}
$\begin{array}{c}\text { Sumber } \\
\text { Perbedaan }\end{array}$ & $\begin{array}{c}\text { Krite- } \\
\text { ria }\end{array}$ & Sig. & $\begin{array}{c}\text { Kesimpu- } \\
\text { lan }\end{array}$ \\
\hline Wet Cell & Sig. $<$ & 0,000 & Berbeda \\
$><$ Standar & 0,05 & & $\begin{array}{c}\text { Signifikan } \\
\text { Berbeda }\end{array}$ \\
Dry Cell & Sig. $<$ & 0,001 & $\begin{array}{c}\text { Signifikan } \\
><\text { Standar }\end{array}$ \\
\hline
\end{tabular}


Berdasarkan ringkasan hasil uji T satu sampel pada Tabel di atas dapat diambil kesimpulan bahwa rerata penggunaan Hydrogen Eco Booster tipe Wet Cell maupun tipe Dry Cell menunjukkan adanya perbedaan yang signifikan dibandingkan dengan rerata kondisi standar emisi gas buang $\mathrm{CO}$ dan $\mathrm{HC}$ sepeda motor.

Tabel 5. Ringkasan Hasil Uji $\mathrm{T}$ Satu Sampel Emisi Gas Buang CO Variasi Jenis Larutan dengan Kondisi Standar

\begin{tabular}{lccc}
\hline $\begin{array}{c}\text { Sumber } \\
\text { Perbedaan }\end{array}$ & Kriteria & Sig. & Kesimpulan \\
\hline Air Murni & Sig. $<$ & 0,020 & Berbeda \\
$><$ Standar & 0,05 & & $\begin{array}{c}\text { Signifikan } \\
\text { Berbeda }\end{array}$ \\
Air Murni & Sig. $<$ & 0,000 & Signifikan \\
$+\mathrm{KOH}><$ & 0,05 & & \\
Standar & & & Berbeda \\
Air Murni & Sig. $<$ & 0,000 & Signifikan \\
$+\mathrm{NaOH}$ & 0,05 & & \\
$><\mathrm{Standar}$ & & & \\
Air Murni & Sig. $<$ & 0,000 & Berbeda \\
$+\mathrm{NaHCO}$ & 0,05 & & Signifikan \\
$><\mathrm{Standar}_{3}$ & & & \\
\hline
\end{tabular}

Tabel 6. Ringkasan Hasil Uji $\mathrm{T}$ Satu Sampel Emisi Gas Buang HC Variasi Jenis Larutan dengan Kondisi Standar

\begin{tabular}{|c|c|c|c|}
\hline $\begin{array}{c}\text { Sumber } \\
\text { Perbedaan }\end{array}$ & Kriteria & Sig. & Kesimpulan \\
\hline $\begin{array}{l}\text { Air Murni } \\
><\text { Standar }\end{array}$ & $\begin{array}{c}\text { Sig. < } \\
0,05\end{array}$ & 0,028 & $\begin{array}{c}\text { Berbeda } \\
\text { Signifikan }\end{array}$ \\
\hline $\begin{array}{l}\text { Air Murni } \\
+\mathrm{KOH}>< \\
\text { Standar }\end{array}$ & $\begin{array}{c}\text { Sig. }< \\
0,05\end{array}$ & 0,000 & $\begin{array}{l}\text { Berbeda } \\
\text { Signifikan }\end{array}$ \\
\hline $\begin{array}{l}\text { Air Murni } \\
+\mathrm{NaOH} \\
><\text { Standar }\end{array}$ & $\begin{array}{c}\text { Sig. }< \\
0,05\end{array}$ & 0,001 & $\begin{array}{c}\text { Berbeda } \\
\text { Signifikan }\end{array}$ \\
\hline $\begin{array}{l}\text { Air Murni } \\
+\mathrm{NaHCO}_{3} \\
><\text { Standar }\end{array}$ & $\begin{array}{c}\text { Sig. }< \\
0,05\end{array}$ & 0,004 & $\begin{array}{c}\text { Berbeda } \\
\text { Signifikan }\end{array}$ \\
\hline
\end{tabular}

Berdasarkan ringkasan hasil uji $\mathrm{T}$ satu sampel pada Tabel di atas dapat diambil kesimpulan bahwa rerata penggunaan Hydrogen Eco Booster semua jenis larutan menunjukkan adanya perbedaan yang signifikan dibandingkan dengan rerata kondisi standar emisi gas buang $\mathrm{CO}$ dan HC sepeda motor.

\section{Uji Scheffe}

Tabel 7. Ringkasan Hasil Uji Scheffe Gas Buang CO Antar Variasi Jenis Larutan

\begin{tabular}{lccc}
\hline $\begin{array}{c}\text { Sumber } \\
\text { Perbedaan }\end{array}$ & Kriteria & Sig. & Kesimpulan \\
\hline Air Murni & Sig. $<$ & 0,000 & Berbeda \\
$><$ Air & 0,05 & & Signifikan \\
Murni + & & &
\end{tabular}

$\mathrm{KOH}$

$\begin{array}{lccc}\text { Air Murni } & \text { Sig. }< & 0,000 & \text { Berbeda } \\ ><\text { Air } & 0,05 & & \text { Signifikan }\end{array}$

Murni +

$\mathrm{NaOH}$

$\begin{array}{lccc}\text { Air Murni } & \text { Sig. }< & 0,000 & \begin{array}{c}\text { Berbeda } \\ \text { Signifikan }\end{array}\end{array}$

Murni +

$\mathrm{NaHCO}_{3}$

Air Murni + Sig. $<\quad 0,999 \quad$ Tidak

$\mathrm{KOH}><$ Air $0,05 \quad$ Berbeda

Murni +

Signifikan

$\mathrm{NaOH}$

Air Murni + Sig. $<\quad 0,977 \quad$ Tidak

$\mathrm{KOH}><$ Air $0,05 \quad$ Berbeda

Murni +

Signifikan

$\mathrm{NaHCO}_{3}$

$\begin{array}{lccc}\text { Air Murni }+ & \text { Sig. }< & 0,948 & \text { Tidak } \\ \mathrm{NaOH}>< & 0,05 & & \text { Berbeda } \\ \text { Air Murni }+ & & & \text { Signifikan } \\ \mathrm{NaHCO}_{3} & & & \end{array}$

$\mathrm{NaHCO}_{3}$

Hasil uji Scheffe pada Tabel 7 menunjukkan bahwa nilai signifikansi bervariatif ada yang lebih besar dan lebih 
kecil dari $\alpha(0,05)$ sehingga dapat diambil kesimpulan sebagai berikut: (1) Rerata penggunaan jenis larutan air murni dengan rerata penggunaan jenis larutan air murni ditambah $\mathrm{KOH}, \quad \mathrm{NaOH}, \quad \mathrm{NaHCO}_{3}$ menunjukkan perbedaan yang signifikan terhadap emisi gas buang $\mathrm{CO}$ sepeda motor, (2) Rerata penggunaan antar jenis larutan air murni ditambah katalis $(\mathrm{KOH}+$ $\mathrm{NaOH}, \mathrm{KOH}+\mathrm{NaHCO}_{3}$, dan $\mathrm{NaOH}+$ $\left.\mathrm{NaHCO}_{3}\right)$ menunjukkan tidak adanya perbedaan yang signifikan terhadap emisi gas buang $\mathrm{CO}$ sepeda motor.

Tabel 8. Ringkasan Hasil Uji Scheffe Gas Buang HC Antar Variasi Jenis Larutan

\begin{tabular}{lccc}
\hline $\begin{array}{c}\text { Sumber } \\
\text { Perbedaan }\end{array}$ & Kriteria & Sig. & Kesimpulan \\
\hline Air Murni & Sig. $<$ & 0,005 & Berbeda \\
$><$ Air & 0,05 & & Signifikan \\
Murni + & & & \\
KOH & & & \\
Air Murni & Sig. $<$ & 0,000 & Berbeda \\
$><$ Air & 0,05 & & Signifikan \\
Murni + & & & \\
NaOH & & & \\
Air Murni & Sig. $<$ & 0,126 & Tidak \\
$><$ Air & 0,05 & & Berbeda \\
Murni + & & & Signifikan \\
NaHCO & & & \\
Air Murni + & Sig. $<$ & 0,103 & Tidak \\
KOH $><$ Air & 0,05 & & Berbeda \\
Murni + & & & Signifikan \\
NaOH & & & \\
Air Murni + & Sig. $<$ & 0,397 & Tidak \\
KOH $><$ Air & 0,05 & & Berbeda \\
Murni + & & & Signifikan \\
NaHCO & & & \\
Air Murni + & Sig. $<$ & 0,004 & Berbeda \\
NaOH $><$ & 0,05 & & Signifikan \\
Air Murni + & & & \\
NaHCO & & & \\
\hline
\end{tabular}

Berdasarkan ringkasan hasil uji Scheffe pada Tabel di atas menunjukkan bahwa nilai signifikansi bervariatif ada yang lebih besar dan lebih kecil dari $\alpha$ $(0,05)$ sehingga dapat diambil kesimpulan sebagai berikut: (1) Rerata penggunaan jenis larutan air murni dengan rerata penggunaan jenis larutan air murni ditambah katalis $\mathrm{KOH}$, dan $\mathrm{NaOH}$, dan rerata penggunaan jenis larutan air murni yang ditambah katalis $\mathrm{NaOH}$ dengan $\mathrm{NaHCO}_{3}$ menunjukkan adanya perbedaan yang signifikan terhadap emisi gas buang HC sepeda motor, (2) Rerata penggunaan jenis larutan air murni dengan rerata penggunaan jenis larutan air murni ditambah katalis $\mathrm{NaHCO}_{3}$ dan rerata penggunaan jenis larutan air murni yang ditambah katalis $(\mathrm{KOH}$ dengan $\mathrm{NaOH}$, dan $\mathrm{KOH}$ dengan $\left.\mathrm{NaHCO}_{3}\right)$ menunjukkan tidak adanya perbedaan yang signifikan terhadap emisi gas buang $\mathrm{HC}$ sepeda motor.

\section{Emisi Gas Buang CO dan HC dengan}

\section{Variasi Tipe Elektroliser}

Berdasarkan hasil uji Anava Dua Jalan menunjukkan bahwa variasi tipe elektroliser mempunyai pengaruh yang signifikan terhadap emisi gas buang $\mathrm{CO}$ dan $\mathrm{HC}$ dengan nilai signifikansi lebih kecil dari taraf signifikansi $0,05(\alpha=5 \%)$. Berdasarkan hasil uji $\mathrm{T}$ satu sampel 
menunjukkan bahwa Hydrogen Eco Booster tipe Wet Cell maupun tipe Dry Cell sama-sama berpengaruh signifikan terhadap penurunan tingkat emisi gas buang $\mathrm{CO}$ dan $\mathrm{HC}$.

Hal ini disebabkan karena Wet Cell dan Dry Cell sama-sama mampu memproduksi gas HHO secara optimal. Penambahan gas HHO ini menyebabkan campuran bahan bakar terbakar lebih sempurna karena dengan penambahan gas ini membuat AFR menjadi sedikit lebih kurus.

\section{Emisi Gas Buang CO dan HC dengan} Variasi Jenis Larutan

Berdasarkan hasil uji Anava Dua Jalan menunjukkan bahwa variasi jenis larutan mempunyai pengaruh yang signifikan terhadap emisi gas buang $\mathrm{CO}$ dan $\mathrm{HC}$ dengan nilai signifikansi lebih kecil dari taraf signifikansi $0,05 \quad(\alpha=5 \%)$. Berdasarkan hasil uji $\mathrm{T}$ satu sampel menunjukkan bahwa penggunaan Hydrogen Eco Booster dengan semua jenis larutan berpengaruh signifikan terhadap penurunan tingkat emisi gas buang $\mathrm{CO}$ dan HC. Perbandingan penggunaan antar jenis larutan yang lain dapat dilihat pada hasil uji Scheffe yang menunjukkan bahwa perbedaan yang signifikan terjadi antara jenis larutan air murni dengan jenis larutan $\mathrm{KOH}, \mathrm{NaOH}$, dan $\mathrm{NaHCO}_{3}$.
Hal ini terjadi karena penggunaan katalis menyebabkan larutan menjadi bersifat elektrolit, sehingga pemisahan gas hidrogen-oksigen pada air atau produksi gas HHO menjadi lebih cepat dibandingkan tanpa menggunakan katalis (air murni).

\section{Interaksi Tipe Elektroliser dan Jenis Larutan terhadap Emisi Gas Buang}

Berdasarkan hasil uji Anava Dua Jalan menunjukkan bahwa interaksi tipe elektroliser dan jenis larutan mempunyai pengaruh yang signifikan terhadap emisi gas buang $\mathrm{CO}$ dan $\mathrm{HC}$ dengan nilai signifikansi lebih kecil dari taraf signifikansi $0,05(\alpha=5 \%)$. Penggunaan Hydrogen Eco Booster tipe Wet Cell maupun Dry Cell dengan variasi jenis larutan menunjukkan penurunan terhadap emisi gas buang $\mathrm{CO}$ dan $\mathrm{HC}$ sepeda motor dibandingkan dengan kondisi standar. Emisi gas CO yang terendah yaitu pada penggunaan Hydrogen Eco Booster tipe Wet Cell sebesar $0,111 \%$ atau terjadi penurunan sebesar $84,41 \%$ pada penggunaan jenis larutan $\mathrm{KOH}$, sedangkan emisi gas $\mathrm{HC}$ terendah yaitu pada penggunaan Hydrogen Eco Booster tipe Dry Cell sebesar 524,33 ppm atau terjadi penurunan sebesar $69,62 \%$ pada penggunaan jenis larutan $\mathrm{NaOH}$. 
Hal ini menunjukkan bahwa kontruksi Wet Cell yang tidak mendukung pelepasan panas dengan baik cocok atau sesuai dengan penggunaan jenis larutan $\mathrm{KOH}$ dan $\mathrm{NaHCO}_{3}$ yang karakteristik reaksinya tidak cepat menghasilkan panas sedangkan pada tipe Dry Cell yang kontruksinya mendukung pelepasan panas cukup baik cocok atau sesuai dengan penggunaan jenis larutan $\mathrm{NaOH}$ yang karakteristik reaksinya cepat menghasilkan panas.

\section{PENUTUP}

\section{Simpulan}

Berdasarkan hasil penelitian, maka disimpulkan beberapa hal sebagai berikut:

1. Ada pengaruh yang signifikan tipe elektroliser pada Hydrogen Eco Booster terhadap penurunan tingkat emisi gas buang (CO dan $\mathrm{HC}$ ) sepeda motor 4 tak, (Sig-value gas $\mathrm{CO}=0.001<\alpha=0.05)$ dan (Sig-value gas $\mathrm{HC}=0.000<\alpha=0.05)$.

2. Ada pengaruh yang signifikan jenis larutan pada Hydrogen Eco Booster terhadap penurunan tingkat emisi gas buang (CO dan $\mathrm{HC}$ ) sepeda motor 4 tak, (Sig-value gas $\mathrm{CO}=0.000<\alpha=0.05$ ) dan (Sig-value gas $\mathrm{HC}=0.000<\alpha=0.05)$.

3. Ada interaksi pengaruh yang signifikan antara tipe elektroliser dan jenis larutan pada Hydrogen Eco Booster terhadap penurunan tingkat emisi gas buang (CO dan HC) sepeda motor 4 tak, (Sigvalue gas $\mathrm{CO}=0.000<\alpha=0.05)$ dan (Sig-value gas $\mathrm{HC}=0.000<\alpha=0.05$ ). Gas CO terendah diperoleh pada tipe Wet Cell dengan jenis larutan $\mathrm{KOH}$ dengan penurunan sebesar 84,41\%. Gas HC terendah diperoleh pada tipe Dry Cell dengan jenis larutan $\mathrm{NaOH}$ dengan penurunan sebesar $69,62 \%$.

\section{Saran}

Berdasarkan hasil penelitian yang telah dilakukan dan dikemukakan maka dapat disampaikan saran-saran sebagai berikut:

1. Bagi pengguna sepeda motor yang ingin mengaplikasikan Hydrogen Eco Booster disarankan memperhatikan tipe elektroliser dan jenis larutan yang akan dipakai.

2. Perlu adanya penelitian lebih lanjut tentang konsumsi listrik dan jenis elektroda yang paling baik pada penggunaan Hydrogen Eco Booster serta pengembangan terhadap alat tersebut.

3. Perlu adanya penelitian lebih lanjut tentang dampak penggunaan Hydrogen Eco Booster untuk jangka panjang.

4. Gas HHO hasil elektrolisis ini diharapkan dapat digunakan sebagai masukan dan pertimbangan pengganti bahan bakar fosil. 


\section{DAFTAR PUSTAKA}

Asosiasi Industri Sepeda Motor Indonesia (2014). Motorcycle Production Wholesales Domestic and Exports. Diperoleh pada 13 Januari 2016, dari http://www.aisi.or.id/statistic/

Badan Standardisasi Nasional. (2005). Emisi Gas Buang - Sumber Bergerak - Bagian 3: Cara Uji Kendaraan Bermotor Kategori L Pada Kondisi Idle (SNI 09-7118.3-2005). Jakarta: BSN.

Bugis, Husin. (2009). System Management Engine. Surakarta: Pendidikan Profesi Guru FKIP UNS.

De Silva, TS., Senevirathne, L., Warnasooriya, TD. (2015). HHO Generator - An Approach to Increase Fuel Efficiency in Spark Ignition Engines. European Journal of Advances in Engineering and Technology, 2 (4): 1-7. Diperoleh pada 15 Februari 2016, dari http://www.ejaet.com/PDF/24/EJAET-2-4-1-7.pdf.

Kementerian Energi dan Sumber Daya Mineral. (2008, 25 Agustus). Potensi Energi Baru Terbarukan (EBT) Indonesia. Diperoleh 23 Januari 2016, dari http://esdm.go.id/berita/umum/37umum/1962-potensi-energi-baruterbarukan-ebt-indonesia.html.

Kementerian Energi dan Sumber Daya Mineral. (2015). Handbook of Energy \& Economic Statistics of Indonesia. Diperoleh pada 14 Februari 2016, dari http://esdm.go.id/publikasi/statistik/h andbook.html.

Melfiana, E., Harto, A.W., \& Agung, A. (2007). Pengaruh Variasi Temperatur Keluaran Molten Salt Reactor Terhadap Efisiensi Produksi Hidrogen dengan Sistem High
Temperatur Electrolysis (HTE). Prosiding Seminar Nasional ke-13 Teknologi dan Keselamatan PLTN serta Fasilitas Nuklir, hlm. 107 112. Universitas Gajah Mada, Jakarta. Diperoleh 12 Januari 2016, dari

Sudirman, Urip. (2008). Hemat BBM dengan Air. Jakarta: Kawan Pustaka.

Sugiyono. (2013). Metode Penelitian Pendidikan (Pendekatan Kuantitatif, Kualitatif, dan R\&D). Bandung: Alfabeta. 